\title{
Tohuma Çinko Uygulama Metodunun Su Kültürü Koșullarında Mısırın Kuru Madde Verimi ve Çinko Konsantrasyonu Üzerine Etkisinin Belirlenmesi
}

\author{
Ayfer ALKAN TORUN ${ }^{1 *} \quad$ Abdullah ER' Halil ERDEM² Bülent TORUN'
}

'Cukurova Üniversitesi, Ziraat Fakültesi, Toprak Bilimi ve Bitki Besleme Bölümü, Adana
${ }^{2}$ Gaziosmanpașa Üniversitesi, Ziraat Fakültesi, Toprak Bilimi ve Bitki Besleme Bölümü, Tokat

*Sorumlu yazar e-posta (Corresponding author e-mail) : atorun@cu.edu.tr

Geliș tarihi (Received) : 01.07 .2016

Kabul tarihi (Accepted) : 21.10 .2016

Öz

Çinko (Zn) bitkisel üretimin ve ürün kalitesinin artırılmasında önemli bir mikroelementir. Ayrıca tanedeki Zn yetersizliği beslenmede dolayısıyla insan sağlığında da ciddi bir problem olarak ortaya çıkabilmektedir. Bu noksanlığının giderilmesi amacıyla, tohumun ekim öncesi Zn’lu çözeltide bekletilmesi sahip olduğu birçok avantaj nedeniyle son zamanlarda ön plana çıkmıș olan bir metottur. Kontrollü koșullarda su kültüründe bu konuda yürütülmüș bir çalıșmaya rastlanmamıștır. Bu çalıșma Zn uygulamalı ( $\left.\mathrm{Zn} 1: 1 \mu \mathrm{M} \mathrm{ZnSO}_{4}\right)$ ve uygulamasız $\left(\mathrm{ZnO}: 0 \mu \mathrm{M} \mathrm{ZnSO}_{4}\right)$ ortamda farklı zaman aralıklarında $10 \mathrm{dk}, 1 \mathrm{dk}, 10 \mathrm{dk}, 30 \mathrm{dk}$ ve $60 \mathrm{dk}) 5 \mathrm{mM} \mathrm{ZnSO}_{4}$ çözeltisinde bekletilmiș mısır (Zea mays L.) tohumlarından elde edilen yaklașı 12 (I. hasat) ve 20 günlük (II. hasat) bitkilerin Zn noksanlığı semptom șiddeti, kök ve yeșil aksam kuru madde verimi ile kök ve yeșil aksam Zn konsantrasyonu üzerine etkisini ortaya koymak amacıyla su kültüründe gerçekleștirilmiștir. Çalıșmada, çözeltiden Zn uygulanmadığında farklı zaman aralıklarında Zn çözeltisinde bekletilmiș tohumlardan elde edilen bitkilerin her iki hasatta da kontrole göre, hem kök hem de yeșil aksam kuru madde verimi ve Zn konsantrasyonunun arttığı belirlenmiștir. Kuru madde verimi açısından sözkonusu artıșlar, özellikle II. hasatta çözeltide bekletilme süresiyle doğru orantılı olmuștur. Çinko konsantrasyonu ise, kuru madde veriminin aksine I. hasatta daha yüksek iken II. hasatta azalmıștır. Özellikle çözeltiden Zn'nun uygulanmadığı koșullarda I. hasata ait yeșil aksam ve kök Zn konsantrasyonu II. hasattan daha yüksek bulunmuștur Sonuç olarak, yetiștirme ortamında Zn'nun yetersiz olduğu koșullarda mısır tohumunu Zn çözeltisi içinde bekletmenin bitkinin Zn noksanlığı semptom șiddeti, kuru madde verimi ve Zn konsantrasyonu üzerinde önemli etkisinin olduğu belirlenmiștir.

Anahtar Kelimeler: Çinko, çözeltide bekletme uygulaması, mısır, noksanlık

\section{Determination of Influence of Zinc Application through Seed Treatment Method on Dry Matter Yield and Zinc Concentration of Corn in Hydroponic Culture Conditions}

\footnotetext{
Abstract

Zinc $(Z n)$ is an important microelement in increasing the yield and quality of plant production. In addition, zinc deficiency in the seed can be a nutritional problem and therefore a serious problem in
} 
human health. In order to overcome the problem Zn application method as priming of seeds in dilute Zn solutions prior to sowing recently came to forward because of having many advantages. No studies under controlled conditions could be met in literature regarding on this subject. This study aimed to find out the effect of plants obtained from seeds of corn (Zea mays L.) which have been soaked in 5 $\mathrm{mM} \mathrm{ZnSO}_{4}$ at different time periods $(0 \mathrm{~min}, 1 \mathrm{~min}, 10 \mathrm{~min}, 30 \mathrm{~min}$ and $60 \mathrm{~min}$ ) grown in with $\mathrm{Zn}$ (Zn: $1 \mu \mathrm{M} \mathrm{ZnSO}_{4}$ ) and without $\mathrm{Zn}\left(\mathrm{Zn:} 0 \mu \mathrm{M} \mathrm{ZnSO}_{4}\right)$ conditions for approximately 12 days (1. harvest) and 20 days (II. harvest) on the severity of Zn deficiency symptoms, root and shoot dry matter yield, as well as the concentration of $\mathrm{Zn}$ in shoot and root in a hydroponic experiment. In this experiment, increases in dry weight and $Z n$ concentration both in shoots and roots of 12 and 20 days harvested plants which of seeds were soaked in $\mathrm{Zn}$ solution at different time periods have been seen in comparison with the control plants. Mentioned increases with respect to dry matter yield increased parallel to the soaking time of seeds in solution especially at II. harvest. In contrast to dry matter yield, Zn concentration was higher in plants obtained at I. harvest while it decreased in plants obtained at II. harvest. Zinc concentrations of plants were found to be higher at I. harvest than those of the ones obtained at II. harvest particularly under the conditions of without Zn application from the solution. As a result, it has been determined that the application method of soaking of the seeds in Zn solution at a certain time has a significant effect on the severity of symptoms of Zn deficiency, dry matter yield and Zn concentration.

Key Words: Zinc, seed dressing, corn, deficiency

\section{Giriș}

Çinko (Zn) noksanlığı dünyada (Ortiz-Manasterio vd., 2007) ve Türkiye'de (Cakmak vd., 2004) çok rastlanan bir mikrobesin elementi problemi olup, dünyada tarım yapılan toprakların \% 50'sinde bitkiye yarayıșlı Zn'nun düșük olduğu ortaya konulmuștur. Türkiye'nin de tarım yapılan topraklarının \% 50'inde ve en önemli tahıl yetiștirme alanı olan Orta Anadolu Bölgesi' nin \% 80'inde Zn noksanlığı mevcuttur (Cakmak vd., 2004). Topraklardaki Zn noksanlığı ile uyumlu olarak, günümüzde dünyada (Gibson, 2006) ve Türkiye'de insanlarda çok yaygın bir biçimde Zn noksanlığı görülmektedir (Cakmak vd., 1999).

Bitkilerdeki Zn noksanlığının giderilmesinde en yaygın olarak kullanılan topraktan Zn uygulama yöntemi bitkisel verimi arttırmada etkin bir yöntem iken (Cakmak vd., 1997; Ekiz vd., 1998; Zhang vd., 2007; Wissuwa vd., 2006), bunun tanedeki Zn'nun insan beslenmesine katkı sağlayıcı boyutta bir artıș sağlamada tek bașına yeterince etkili bir yol olmadığı belirtilmiștir. Yılmaz ve vd., (1997) tarafından buğdayda yürütülen bir çalıșmada Zn'nun toprak, yaprak, tohum, toprak+yaprak ve yaprak+tohum uygulamasıyla, kontrole göre tane veriminde önemli bir artıșın sağlandığı belirlenmiștir. IIlgili çalıșmada yalnızca toprak uygulamasında tane Zn konsantrasyonu $17 \mathrm{mg} \mathrm{kg}^{-1}$ iken, yaprak, toprak+yaprak ve tohum+yaprak uygulamalarında aynı değerin 27-35 mg kg-1 arasında değiștiği görülmüștür. Yapraktan Zn uygulama zamanının da tane Zn'sunun arttırılmasında çok önemli bir faktör olduğu bildirilmiștir (Öztürk vd., 2006; Cakmak, 2008). Tane dolum așamasında buğday tanesindeki Zn konsantrasyonunun değișiminin izlendiği bir çalıșmada, tanede en yüksek Zn konsantrasyonunun süt dolum döneminde gerçekleștiği görülmüștür (Öztürk vd., 2006).

Tanedeki mikroelement içeriğinin arttııımasında topraktan ve yapraktan gübreleme yöntemlerinin yanı sıra, literatürlerde "seed priming" veya "seed dressing" olarak ifade edilen tanenin mikroelement içeren çözeltide bekletilmesinin (Prom-u-thai vd., 2012) ekim öncesi tanedeki mikroelement içeriğini arttırmada en pratik ve kolay uygulanabilir yöntemlerinden biri olduğu son yıllarda tarla koșullarında yapılan birçok çalıșmayla gösterilmiștir (Ajouri vd., 2004; Foti vd., 2008; Harris vd., 2007; Afzal, 2013). Bu çerçevede Harris vd,. (2007) tarafından ekim öncesi tanenin $\mathrm{Zn}$ içeren çözeltilerde bekletilmesinin pratik bir yöntem olduğu ve daha iyi bir çimlenmeye yol açtığı bildirilmiștir. İlgili çalıșmada, mısır tohumu \% l'lik $\mathrm{ZnSO}_{4}$ çözeltisinde 16 saat bekletildikten sonra ekimi yapılmıș ve \% 1 'lik $\mathrm{ZnSO}_{4}$ çözeltisi ile doyurulmadan önce tohumdaki Zn konsantrasyonu $15 \mathrm{mg} \mathrm{kg}^{-1}$ olduğu sonrasında bu değerin $560 \mathrm{mg} \mathrm{kg}^{-1}$ olduğu bildirilmiștir. Zn'lu çözeltide bekletilmiș tohumlardan elde edilen bitkinin daha fazla biyomas ürettiği ve 
daha fazla dane verimi gerçekleștirerek kontrole göre \% 27'lik bir verim artıșı sağladığı belirtilmiștir. Bu da ekimden önce tohumların Zn'lu çözeltide bekletilmesinin yalnızca tane Zn'sunun artıșı için değil, verim artıșında da etkili olduğuna ișaret etmektedir. Çalıșmada karlıı/maliyet oranı toprak uygulamasında düșük iken, tohumdan uygulamada yüksek olduğu bildirilmiștir. Topraktan hektara 2,75 kg Zn atılmasına karșilık, tohum doyurulma ișleminde $1 \mathrm{~kg}$ tohumun 1,5 litrelik \% 1'lik Zn çözeltisi ile muamele edilmesi de maliyette önemli bir tasarruf sağladığı tepit edilmiștir.

Özellikle tohumun Zn'lu çözeltide bekletilmesi uygulama șekli ve uygulama zamanının birçok bitki gruplarında kontrollü șartlar altında su kültürü ortamında etkisine ilișkin çalıșmalar neredeyse yok dencek azdır. Örneğin ülkemizin ve özellikle Çukurova Bölgesi' nin önemli bitkisel üretim gruplarından birini olușturan mısır bitkisinde bu konuda çalıșmalar son derece yetersizdir. Bu nedenle yürütülen bu çalıșmada, sera koșulları altında çözeltiden Zn uygulanan ve uygulanmayan su kültürü ortamında, Zn çözeltisi içerisinde bekletilerek $Z n$ ile zenginleștirilmiș mısır tohumlarının bünyelerine aldıkları Zn'nun deneme süresince bitkilerde Zn eksikliği semptomları, kök ve yeșil aksam kuru madde verimi ve kök ve yeșil aksam Zn konsantrasyonu üzerine etkisinin iki farklı hasatla ortaya konulması amaçlanmıștır.

\section{MATERYAL VE YÖNTEM}

Su kültürü denemesinde bitki materyali olarak iyi çimlenme özelliğine sahip Yeni Doga mısır (Zea mays L.) çeșidi kullanıımıștır. Su kültürü koșullarında yürütülen deneme, farklı zaman aralıklarında ( 1 dk, 10 dk, 30 dk, ve 60 dk) 5 mM ZnSO 4 çözeltisinde bekletilmiș tohumların deneme süresince besin çözeltisine $Z n$ uygulanmamıș (ZnO) ve $1 \mu \mathrm{M} Z \mathrm{Zn}$ uygulanmıș $(Z n 1)$ ortamlarda yetiștirilen 2 farklı konudan olușmuștur.

Tohumlar, içerisinde perlit bulunan çimlenme kutularına ekilmiș ve 4-5 gün içerisinde transfer büyüklüğüne ulașan bitkiler, içerisinde mısır bitkisi için hazırlanmıș besin çözeltisi $\left(2.0 \mathrm{mM} \mathrm{Ca}\left(\mathrm{NO}_{3}\right)_{2} ; 0.7\right.$ $\mathrm{mM} \mathrm{K}_{2} \mathrm{SO}_{4} ; 0.1 \mathrm{mM} \mathrm{KH}_{2} \mathrm{PO}_{4} ; 0.1 \mathrm{mM} \mathrm{KCl} ; 0.5 \mathrm{mM}$ $\mathrm{MgSO}_{4} ; 1 \mu \mathrm{M} \mathrm{H}_{3} \mathrm{BO}_{3} ; 0.5 \mu \mathrm{M} \mathrm{MnSO}_{4} ; 100 \mu \mathrm{M} \mathrm{Fe}-$ EDTA; $\left.0.2 \mu \mathrm{M} \mathrm{CuSO}_{4} ; 0.01 \mu \mathrm{M}\left(\mathrm{NH}_{4}\right)_{6} \mathrm{Mo}_{7} \mathrm{O}_{24}\right)$ bulunan saksılara her saksıda 6 bitki olacak șekilde transfer edilmiștir (Șekil 1).

Bitkiler 4 gerçek yaprakı așamaya gelinceye kadar düșük düzeyde (1/2) besin çözeltisi ile yetiștirilmiș ve bu așamadan sonra bu doz iki katına çıkarılmıștır. Bitkilerin bulunduğu besin çözeltisi ortamı deneme süresince havalandırılarak, her üç günde bir yenisi ile değiștirilmiș ve saksıların yerleri değiștirilerek ıșık ve sıcaklıktan tüm bitkilerin eșit șekilde yararlanmaları sağlanmıștır. Deneme süresince I. hasatta 4 bitki, II. hasatta 2 bitki hasat edilmiștir (Șekil 2).

Çinko noksanlığı semptomları hafif görülmeye bașladığında ve bitkiler 12 günlükken I. hasat ve noksanlık semptomları iyice șiddetlendiğinde 120 günlük) II. hasadı yapıımıștır. Saksı yüzeyinin $2 \mathrm{~cm}$ üzerinden porselen makas kullanılarak hasat edilen bitki materyalleri saf su ile yıkanarak 48 saat boyunca $70{ }^{\circ} C^{\prime}$ ye ayarlanmıș etüvde kurutulup, kuru ağırlıkları alınmıștır. Agat değirmeninde öğütülen ve analize hazır hale getirilen bitki örneklerinden 0,2 $\mathrm{g}$ alınmıș

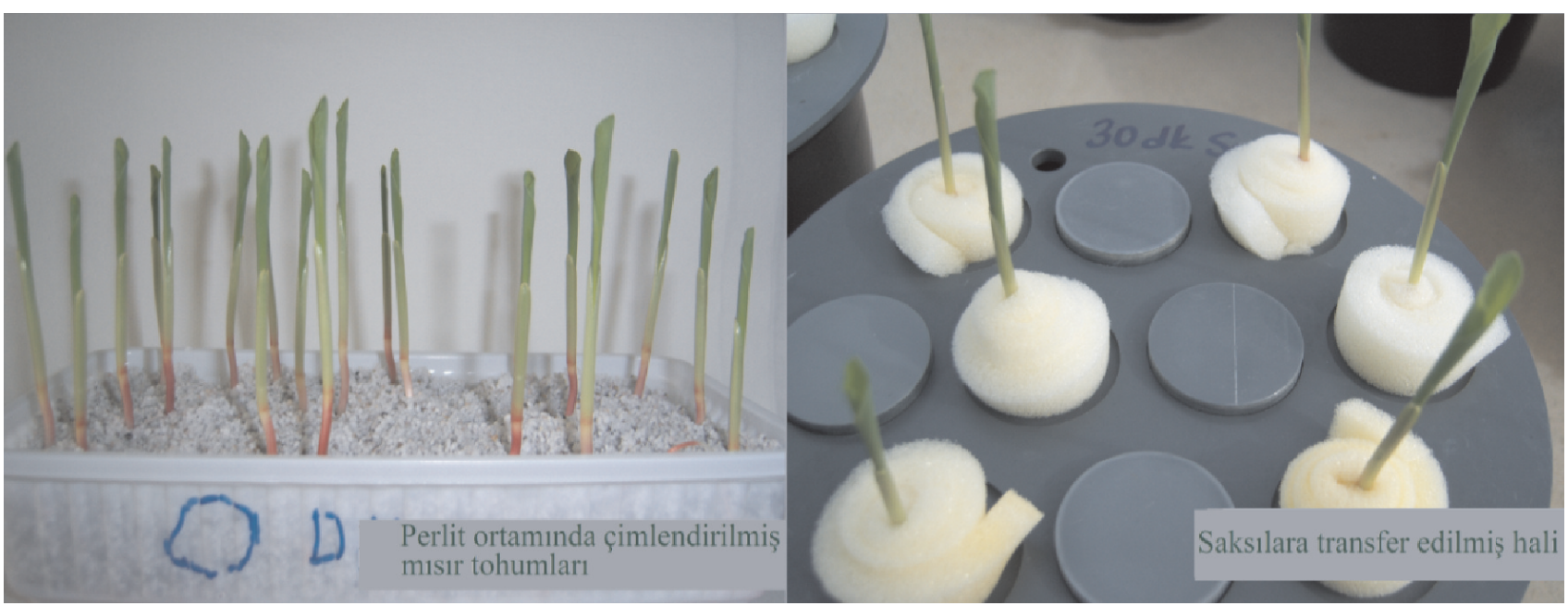

Șekil 1. Perlit ortamında çimlendirilmiș mısır tohumları ve transfer büyüklüğüne gelen bitkilerin süngerle bitki kök boğazından sarılarak saksılara yerleștirilmiș hali

Figure 1. Corn seeds germinated in perlite medium and the the view of placed in pots of the seedlings grown to the transferable height and wrapped with sponge from root collar 

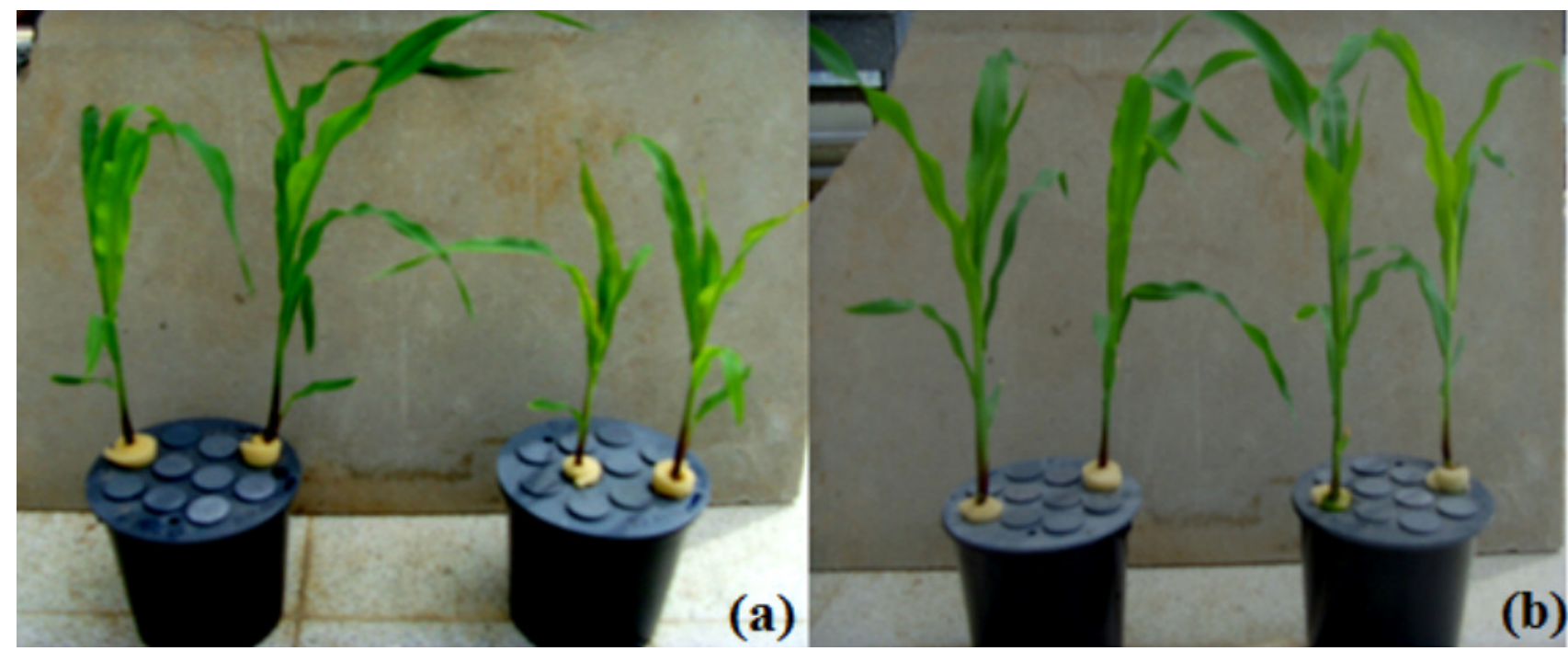

Șekil 2. Solda çözeltiden Zn uygulanmayan ve ekim öncesi tohumu 60 dk Zn çözeltisinde bekletilen bitki ve sağda kontrol bitkisi (a), deneme süresince besin çözeltisine $\mathrm{Zn}$ uygulanmıș (soldaki) bitki ile ekim öncesi tohumu $60 \mathrm{dk}$. $\mathrm{ZnSO}_{4}$ çözeltisinde bekletilmiș ve besin çözeltisine Zn uygulanmamıș (sağdaki) bitki (b)

Figure 2. The plant not applied Zn and soaked $60 \mathrm{~min}$ in $\mathrm{Zn}$ solution before sowing at left and the control plant at right (a) The plant applied Zn during the experiment (at left) with the plant soaked $60 \mathrm{~min} \mathrm{ZnSO}_{4}$ solution and the plant not applied Zn (at right) (b)

ve yaș yakma metoduna göre Milesttone marka mikrodalga firınında $2 \mathrm{ml} \mathrm{H}_{2} \mathrm{O}_{2}-5 \mathrm{ml} \mathrm{HNO}$ asit karıșımında $45 \mathrm{dk}$ süreyle yakılıp, mavi bantlı filtre kağıdında süzülmüștür. Süzülen örneklerin son hacmi saf su ile 20 ml'ye tamamlanmıs ve elde edilen süzükte Zn ölçümü AAS cihazında yapılmıștır.

Araștırma tesadüf parselleri deneme desenine göre, üç tekerrürlü olarak kurulmuș ve elde edilen veriler MSTAT-C bilgisayar programı kullanılarak istatistiksel analiz yapıımıș, ortalamalar arasındaki farklar Duncan ile belirlenmiștir. Elde edilen değerler çizelge ve șekillerde ortalama \pm standart hata șeklinde ifade edilmiștir. Karșılaștırmalarda önem seviyesi $\mathrm{p} \leq 0,05$ olarak alınmıștır.

\section{BULGULAR VE TARTIȘMA}

Çalıșmada mısır bitkisinin Zn noksanlığı semptomları gözlenmiș, yeșil aksam ve kök kuru madde verimi ( $g$ bitki $^{-1}$ ) ile yeșil aksam ve kök Zn konsantrasyon (mg kg-1) değerleri belirlenmiștir.

\section{Çinko Noksanlığı Semptomları}

Çinko noksanlığı semptomları, bitkilerin su kültürüne transferinden 8-9 gün sonra çözeltiden Zn verilmeyen bitkilerin genç yapraklarında damarlar arası sararmalar șeklinde kendini göstermiștir (Șekil 3). Çinko noksanlığı semptomları gösteren bitkilerin boyu ve boğum araları, tam besin çözeltisi verilen bitkilere göre daha kısa olduğu gözlenmiștir. Deneme sonuçları Cakmak vd., (2010) ile uyumlu Zn noksanlık belirtileri göstermiștir.

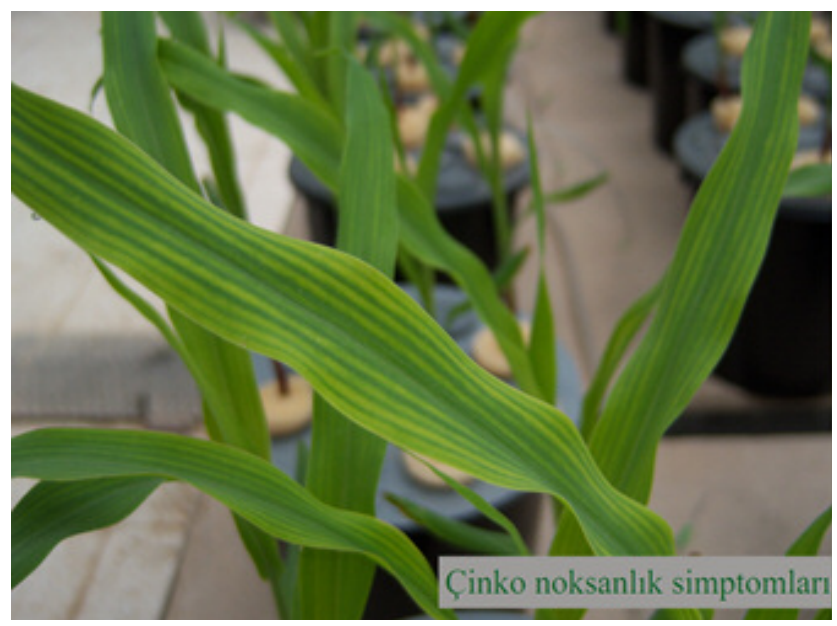

Sekil 3. Cinko verilmeyen bitkilerde tipik genç yapraklarda sararmıș damarlar arası sararmalar

Figure 3. Typical chlorotic interrips necrosis on young leaves not given zinc

Çinko uygulanmayan koșullarda, farklı zaman aralıklarında Zn çözeltisinde bekletilmiș bitkilerden sadece tohumu 60 dk Zn çözeltisinde bekletilmiș bitkiler Zn uygulanmıș bitkilerle aynı gelișimi göstermiștir (Șekil 2). Çinko uygulanmayan saksılarda bitki büyümesinde gerileme ve yapraklarında Zn noksanlığı belirtileri gözlenmiștir.

\section{Yeșil Aksam ve Kök Kuru Madde Verimi (I. Hasat)}

Ekim öncesi tohumları farklı zaman $11 \mathrm{dk}, 10 \mathrm{dk}$, $30 \mathrm{dk}$ ve $60 \mathrm{dk}$ ) aralıklarında $5 \mathrm{mM} \mathrm{ZnSO}_{4}$ çözelti içerisinde bekletilen mısır bitkisinin su kültürü koșullarında kök ve yeșil aksam kuru madde verimleri Çizelge 1'de verilmiștir. 


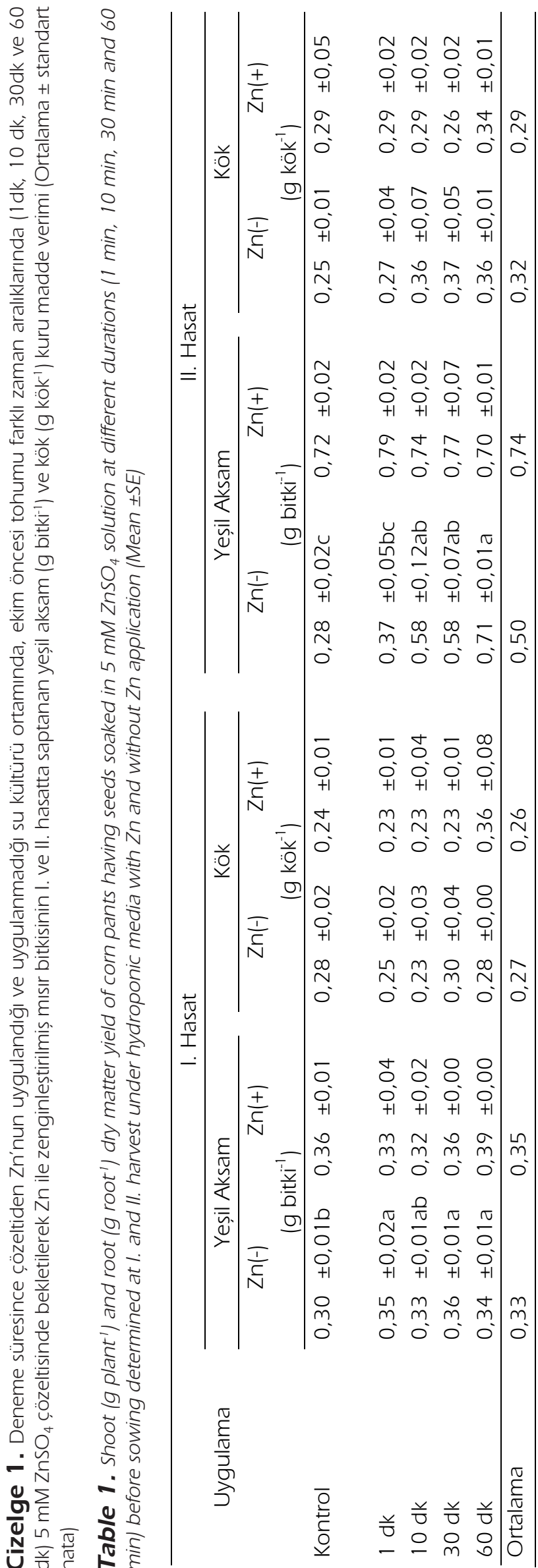

Farklı zaman aralıklarında tohumu Zn çözeltisinde bekletmek, hem I. hasatta hem de özellikle II. hasatta bitkinin kuru madde veriminde önemli farklılıklara yol açmıștır. Ancak, söz konusu farklııkların çözeltiden Zn uygulamasına göre Zn0 uygulanmasında daha da belirgin olduğu görülmüștür. Örneğin, I. hasatta kontrole göre Zn'suz koșullarda tohumdan uygulama ortalama \% 15'lik verim artıșı sağlarken, Zn'lu uygulamada $\left(0,35 \mathrm{~g} \mathrm{bitki}^{-1}\right)$ kontrole $\left(0,36 \mathrm{~g} \mathrm{bitki}^{-1}\right)$ göre çözeltide bekletme uygulaması herhangi bir verim artıșı sağlamamıștır. Çözeltiden Zn'nun uygulanmadığı koșullarda tohumu çözeltide bekletme uygulaması kontrole göre istatistiksel olarak da anlamlıdır $(p<0,05)$. Ancak, yeșil aksamın aksine Zn'suz koșullarda kontrole göre tohumu farklı zaman aralıklarında Zn'da bekletilen bitkinin kök veriminde söz konusu verim artıșı görülmemiștir. Aynı hasat içerisinde kontrolün kök kuru madde verimi 0,28 $\mathrm{g} \mathrm{kök}^{-1}$ iken, farklı zaman aralıklarında 5 mM' ık $\mathrm{ZnSO}_{4}$ çözeltisinde bekletilen bitkinin ortalama kök kuru madde verimi 0,27 $\mathrm{g} \mathrm{kök}^{-1}$ olarak belirlenmiștir. Dolayısıyla Zn'suz koșullarda çözeltide bekletme uygulaması yeșil aksamda yol açtığı artıș kök veriminde görülmemiș ve benzer durum Zn uygulaması altındaki köklerde de devam etmiștir (Çizelge 1).

I. hasatta, çözeltiden Zn'nun uygulanmadığı koșullarda tohumu farklı zaman aralıklarında Zn çözeltisinde bekletilen bitkinin ortalama verimi $\left(0,33 \mathrm{~g} \mathrm{bitki}^{-1}\right)$ kontrol verimine $\left(0,30 \mathrm{~g} \mathrm{bitki^{-1 }}\right)$ göre artarken, ancak uygulama süresine bağlı bir değișim söz konusu olmamıștır. Örneğin, kontrol koșullarında tohumu 1 dk Zn ile muamele edilmiș

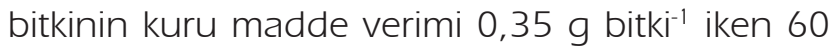
dk muamele edilen bitkide aynı değerin 0,34 $g$ bitki-1 olduğu görülmüștür.

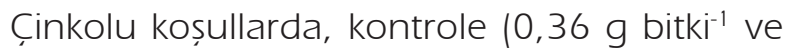
$0,24 \mathrm{~g} \mathrm{kök}{ }^{-1}$ l göre tohumu $60 \mathrm{dk} \mathrm{ZnSO}_{4}$ çözeltisinde bekletilen bitkinin hem yeșil aksam (0.39 $\mathrm{g} \mathrm{bitki}^{-1}$ ) hem de kök kuru madde veriminde (0,36 $\left.\mathrm{g} \mathrm{kök}^{-1}\right)$ artıșa yol açmıștır. Diğer taraftan ekim öncesi farklı zaman aralıklarında $Z^{\prime}$ ' lu çözeltide bekletilmiș tohumlardan elde edilen bitkilere çözeltiden Zn uygulaması çok önemli farklıık yaratmamıștır. Örneğin, I. hasatta farklı zaman aralıklarında ' $\mathrm{Zn}$ ' lu çözeltide bekletilmiș tohumlardan elde edilen bitkilerin ortalama yeșil aksam verimleri Zno (0,33 $\mathrm{g}$ bitki $\left.^{-1}\right)$ koșullara göre Zn1 (0,35 $\left.\mathrm{g} \mathrm{bitki}^{-1}\right)$ koșullarında sadece $\% 6$ artıș göstermiștir. Bu durum tohumu ekim öncesi Zn' lu 
çözeltide bekletme uygulamasının verim artıșı üzerinde önemli bir etkisinin olduğunu göstermektedir. Harris vd., (2007), ekim öncesi tohumu Zn içeren çözeltilerde bekleterek doyurmanın hem pratik hem de daha iyi bir çimlenmeye yol açtığını bildirmișlerdir. Söz konusu çalıșmada, mısır tohumunu \% l'lik $\mathrm{ZnSO}_{4}$ çözeltisinde 16 saat beklettikten sonra ekimi yapılmıștır. Araștırıcılar çinko ile doyurulmamıș tohumlarla yetiștirilen bitkinin dane verimi 3,0 ton ha' ${ }^{-1}$ iken, doyurulmuș $\left(\% 1 \mathrm{ZnSO}_{4}\right)$ tohumlardan elde edilen verimin ise 3,8 ton ha-1 olduğu ve kontrole göre \% 27'lik bir verim artıșı olduğunu bildirmișlerdir. Dolayısıyla ekim öncesi tohumu Zn'lu çözeltilerde bekletme uygulamasının bitkinin kuru madde verimi üzerine çok önemli etkisinin olabileceğini göstermiștir.

\section{Yeșil Aksam ve Kök Kuru Madde Verimi (II. Hasat)}

Deneme süresince çözeltiye $\mathrm{Zn}$ verilmemiș (ZnO) ve farklı zaman aralıklarında tohumu $\mathrm{ZnSO}_{4}$ çözeltisinde bekletilen bitkilerin II. hasat sonrası saptanan kök ve yeșil aksam verimlerinin $Z n^{\prime}$ lu koșullara (Zn1) göre daha fazla etkilendiği görülmüștür. Çinkosuz koșullarda kontrole göre (0.28 $\left.\mathrm{g} \mathrm{bitki}^{-1}\right)$ tohumu Zn'lu çözeltide bekletme uygulaması (0.50 $\mathrm{g} \mathrm{bitki}^{-1}$ ) yaklașı \% 79'luk bir artıș sağlarken, Zn uygulaması (0.74 $\mathrm{g}^{\text {bitki-1)}}$ altında kontrole $\left(0.72 \mathrm{~g} \mathrm{bitki}^{-1}\right)$ göre söz konusu artıșın \% 3 olduğu görülmüștür. Aynı koșullarda kontrol uygulamasında ortalama kök verim \%28 artarken, Zn uygulaması altında kökte herhangi bir verim artıșı görülmemiștir.

I. hasatın aksine, Z Zn' nun uygulanmadığı koșullarda ekim öncesi tohumu farklı zaman aralıklarında $\mathrm{Zn}$ ile muamele edilen bitkinin uygulama süresine bağlı olarak da veriminde önemli artıș gözlenmektedir. Kontrol uygulamasına $\left(0,28 \mathrm{~g} \mathrm{bitki}^{-1}\right)$ göre $1 \mathrm{dk}, 10 \mathrm{dk}, 30 \mathrm{dk}$ ve $60 \mathrm{dk}$ 'lık uygulamalar (sırasıyla 0,$37 ; 0,58,0,58$ ve $0,71 \mathrm{~g}$ bitki ${ }^{-1}$ ) sırasıyla \% 32, \% 105, \% 107 ve \% 153'lük bir artıșa yol açmıștır. Aynı koșullarda yeșil aksama benzer șekilde uygulama süresine bağı olarak kök verimi de artmıștır. Örneğin, kontrol uygulamasına $\left(0,25 \mathrm{~g} \mathrm{kök}^{-1}\right)$ göre $1 \mathrm{dk}, 10 \mathrm{dk}, 30 \mathrm{dk}$ ve $60 \mathrm{dk}^{\prime} / \mathrm{lk}$ uygulamaları kök kuru madde verimini sırasıyla \% 8, \% 44, \% 48 ve \% 44 oranında arttırmıștır (Çizelge 1). Aynı șekilde çözeltiden Zn'nun uygulanmadığı koșullarda tohumdan uygulama kontrole göre istatistiksel olarak anlamlı olmuștur.
I. hasatta olduğu gibi tohumdan uygulama, Zn'suz koșullara göre Zn'lu koșullardaki ortalama yeșil aksam ve kök verimine etkisinin önemsiz olduğu görülmüștür (Çizelge 1). Deneme süresince çözeltiden Zn uygulanmamıș sadece tohumları 60 dk. 5 mM'lık $\mathrm{ZnSO}_{4}$ çözeltisinde bekletilen bitki ile çözeltiden Zn uygulanmıș 60 dk. 5 mM'lık $\mathrm{ZnSO}_{4}$ çözeltisinde bekletilen bitkinin yeșil aksam kuru

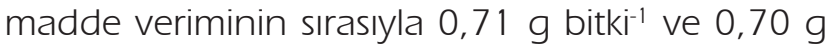
bitki $^{-1}$ olduğu görülmüș ve her iki uygulama altındaki bitkilerin gelișiminin birbirine benzer olduğu Çizelge 1 ve Șekil 2'de görülmektedir. Sonuçlar, Zn noksanlığına sahip büyüme ortamında, ekim öncesi tohumu Zn'lu çözeltide bekletme uygulamasının bitkilerin kuru madde verim artıșı üzerinde önemli etkisi olduğunu ve uygulanan Zn'nun bitkilerin ilk büyüme dönemi için yeterli olması nedeniyle herhangi bir uygulama yapılmasına gerek olmadığını göstermektedir. Bu konuda yapılımıș çalıșmalardan farklı olarak tohumu çözeltide bekletme șeklinde Zn ile doyurmanın su kültürü koșullarında verim üzerindeki bu söz konusu etkisi literatür bulgularını destekler niteliktedir.

\section{Yeșil Aksam ve Kök Zn Konsantrasyonu (I. ve II. Hasat)}

Su kültürü ortamında yürütülen çalıșmanın I. ve II. hasadında elde edilen kök ve yeșil aksam Zn konsantrasyon değerleri Çizelge $Z^{\prime}$ de verilmiștir. Çalıșmada tohumu ekim öncesi Zn' lu çözeltide bekletme uygulaması, çözeltiden Zn uygulanmıș ve uygulanmamıș koșullarda yetiștirilen bitkilerin yeșil aksam ve kök Zn konsantrasyonlarını arttırmıștır. Söz konusu artıș özellikle $Z n^{\prime}$ suz koșullarda tohumun Zn ile doyurulduğu uygulama altında daha belirgin olmuștur. Örneğin, kontrol uygulamasında bitkinin yeșil aksam Zn konsantrasyonu 13,4 $\mathrm{mg} \mathrm{kg}^{-1}$ iken, tohumu $1 \mathrm{dk}, 10 \mathrm{dk}, 30 \mathrm{dk}$ ve $60 \mathrm{dk}$ çözeltide bekletilen bitkinin yeșil aksam Zn konsantrasyonunun sırasıyla 15,3; 22,0; 21,6 ve $33,4 \mathrm{mg} \mathrm{kg}^{-1}$ olduğu ve yeșil aksam Zn konsantrasyonu ortalama $23,1 \mathrm{mg} \mathrm{kg}^{-1}$ olarak hesaplanmıștır. Kontrole göre en büyük artıș tohumu çözeltide 60 dk bekletilen bitkilerde görülmüș ve yeșil aksam Zn konsantrasyonu yaklașık 2,5 kat artmıștır Bu sonuçlar, tohumları ekim öncesi Zn cözeltisinde bekletmenin ve bekletme süresine bağlı olarak bitkinin yeșil aksamındaki Zn konsantrasyonunun artabileceğini 
göstermektedir. Aynı uygulamadaki köke ait Zn konsantrasyon artıșı da yeșil aksamdaki artıșa benzer bir artıș göstermiș ve en yüksek Zn konsantrasyon artıșı tohumu 60 dk Zn çözeltisinde bekletilen bitkinin kök değerlerinde saptanmıș ve sözkonusu değerin $84,6 \mathrm{mg} \mathrm{kg}^{-1}$ olduğu görülmüștür. Aynı koșullarda kontrole ait kök Zn konsantrasyonu $22,8 \mathrm{mg} \mathrm{kg}^{-1}$ ve zamana bağlı olarak tohumu $1 \mathrm{dk}, 10 \mathrm{dk}$ ve $30 \mathrm{dk}^{\prime}$ da $\mathrm{ZnSO}_{4}$ çözeltisinde bekletilen bitkinin köke ait Zn konsantrasyon değerlerinin sırasıyla 34,7; 63,7 ve $68,3 \mathrm{mg} \mathrm{kg}^{-1}$ olduğu saptanmıștır. Elde edilen değerler çözeltiden Zn uygulaması altında daha büyük görünse de kontrole göre $Z n$ konsantrasyon artıșı tohumu Zn'lu çözeltide bekletme uygulaması altında \% 74 iken çözeltiden Zn uygulaması altında \% 39 olmuștur.

II. hasatta da yeșil aksam ve köke ait Zn konsantrasyonu, tohumları Zn çözeltisinde bekletme süresine bağlı olarak artıș eğilimi göstermiștir. Örneğin, I. hasatta 30dk çözeltide bekletilen bitkinin yeșil aksam ve kök Zn konsantrasyonu sırasıyla $21,6 \mathrm{mg} \mathrm{kg}^{-1}$ ve $68,3 \mathrm{mg}$ $\mathrm{kg}^{-1}$ iken II. hasatta aynı değerler $16,3 \mathrm{mg} \mathrm{kg}^{-1}$ ve $35,6 \mathrm{mg} \mathrm{kg}^{-1}$ olarak hesaplanmıștır. İstatistiki olarak da kontrole göre $30 \mathrm{dk}$ 'da $p<0,01$ ve $60 \mathrm{dk}$ uygulamayla arasında <0,05 düzeyindedir. Ancak kuru madde veriminin aksine yeșil aksam konsantrasyonları I. hasattan daha düșük değerler göstermiștir. Bu durum yeșil aksam artıșına bağlı olarak büyüme seyrelme șeklinde yorumlanmıștır.

Diğer taraftan çözeltiden Zn uygulaması altında ekim öncesi tohuma Zn uygulaması yeșil aksam ve kök Zn konsantrasyonunu artırmıștır. Örneğin, II. hasatta sadece tohumu Zn'ca zenginleștirilmiș bitkinin yeșil aksam Zn konsantrasyonu ortalama $13,0 \mathrm{mg} \mathrm{kg}^{-1}$ iken hem Zn'lu çözeltide bekleterek tohumu Zn'ca zenginleștirme hem de çözeltiden Zn uygulaması altında ortalama Zn konsantrasyonunun 47,9 mg $\mathrm{kg}^{-1}$ olduğu görülmüștür. Aynı durum kök konsantrasyonunda da görülmüș ve sırasıyla $32,3 \mathrm{mg} \mathrm{kg}^{-1}$ ve $88,5 \mathrm{mg} \mathrm{kg}^{-1}$ olarak belirlenmiștir. Benzer eğilim I. hasatta da belirlenmiștir. Bu durum ekimden önce tohumu Zn çözeltisinde bekleterek tohumu $\mathrm{Zn}$ ile zenginleștirme uygulamasının Zn konsantrasyonunu arttırdığını ancak bitkinin gelișmesinin ileri așamalarında sözkonusu uygulamanın yetersiz kaldığını ve ilave Zn' ya intiyaç duyulabileceğini göstermektedir.

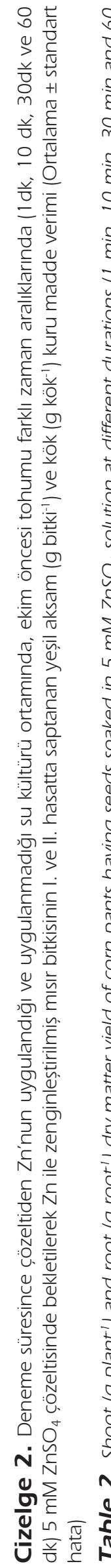

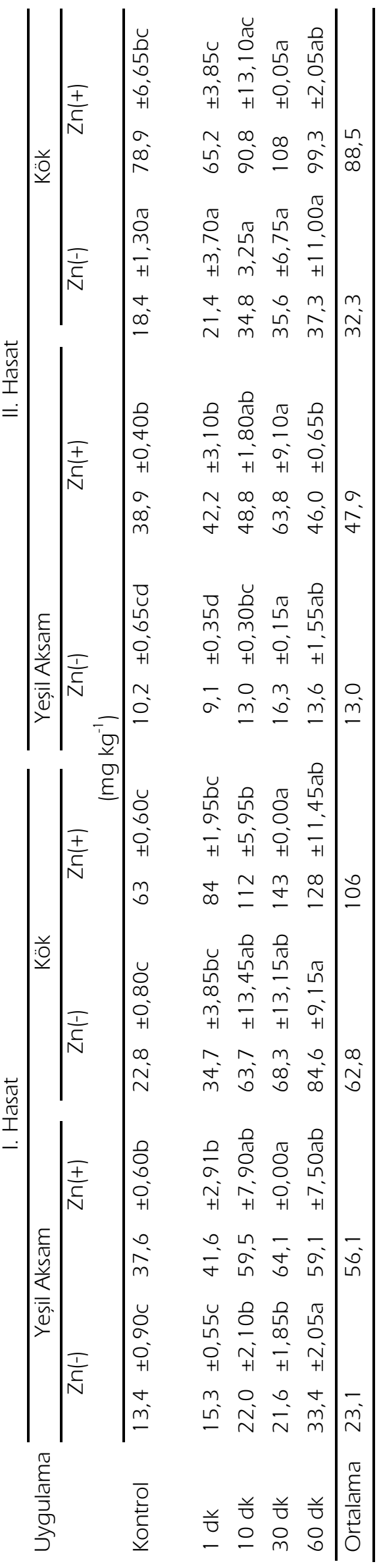


Tohumu Zn' lu Çözeltide Bekletme Uygulamasının Bitkinin Kuru Madde Verimi ve Zn Konsantrasyonları Arasındaki Korelasyon ìlișkileri

Çinkolu ve Zn' suz koșullar altında sadece tohumu Zn' lu çözeltide bekletme uygulaması yapılmıș mısır bitkisinde iki hasat dönemindeki kök ve yeșil aksam kuru madde verimi ve kök ile yeșil aksam Zn konsantrasyonları arasındaki korelasyon ilișkileri belirlenerek Çizelge 3 ve 4'de gösterilmiștir.

Buna göre Zn' suz koșullar altında II. hasat yeșil aksam ile kök kuru madde verimi $0.906^{* *}$, I. hasat yeșil aksam konsantrasyonu $0.818^{*}$ ve I. hasat kök konsantrasyonu $0.827^{* *}$ arasında 0,01 düzeyinde yüksek ve olumlu bir korelasyon; I. hasat kök ile yeșil aksam konsantrasyonu 0,880* ve II. hasat kök ile yeșil aksam konsantrasyonu $0,785^{* *}$ arasında yine 0,01 düzeyinde yüksek ve olumlu korelasyon görülmüștür (Çizelge 3).
Çinkolu koșullar altında ise I. hasat kök ve yeșil aksam konsantrasyonu $0,871^{* *}$ ve II. hasat yeșil aksam konsantrasyonu $0,859^{* *}$ ve I. hasat kök konsantrasyonu ve II. hasat yeșil aksam konsantrasyonu 0,871**arasında 0,01 düzeyinde yüksek ve olumlu korelasyon görülmüștür (Çizelge 4).

Denemede ekimden önce farklı zaman aralıklarında Zn' lu çözeltide bekletilen tohumlardan elde edilen bitkilerin yeșil aksam ve kök kuru madde verimi (Çizelge 1) ile Zn konsantrasyon değerlerinde (Çizelge 2) artıs gözlenmiștir. Yeșil aksam kuru madde verimindeki artıș I. hasatta \% 15 iken bu değer II. hasatta \% 79 olarak hesaplanmıștır.

Zamana bağı olarak tohumu Zn' lu çözeltilerde bekletme uygulaması, bitkinin yeșil aksam ve kök Zn konsantrasyonunu da artırmıș ve sözkonusu artıș I. hasatta daha belirgin iken II. hasatta daha düșük oranda olduğu görülmüștür (Çizelge 2). Sözkonusu

Cizelge 3. Deneme süresince çözeltiden Zn' nun uygulandığı su kültürü ortamında, ekim öncesi tohumu farklı zaman aralıklarında ( $1 \mathrm{dk}, 10 \mathrm{dk}, 30 \mathrm{dk}$ ve $60 \mathrm{dk}) 5 \mathrm{mM} \mathrm{ZnSO}_{4}$ çözeltisinde bekletilerek Zn ile zenginleștirilmiș mısır bitkisinin I. ve II. hasatta saptanan mısır bitkisinin kök ve yeșil aksam kuru madde verimi ve kök ile yeșil aksam Zn konsantrasyon arasındaki korelasyon

Table 3. Correlation between root and shoot dry matter yield and root and shoot Zn concentration of corn plants having seeds soaked in $5 \mathrm{mM} \mathrm{ZnSO}_{4}$ solution at different durations $(1 \mathrm{~min}, 10 \mathrm{~min}, 30 \mathrm{~min}$ and $60 \mathrm{~min}$ ) before sowing determined at I. and II. harvest under hydroponic media with Zn application

\begin{tabular}{llllllll}
\hline Zn $(-)$ & & & & & & & \\
\hline & Km-Y1 & Km-K1 & Km-Y2 & Km-K2 & Kons-Y1 & Kons-K1 & Kons-Y2 \\
\hline KM-K1 & 0,083 & & & & & & \\
KM-Y2 & 0,501 & 0,251 & & & & & \\
KM-K2 & 0,408 & 0,381 & $0,906^{* *}$ & & & & \\
Kons-Y1 & 0,282 & 0,148 & $0,818^{* *}$ & 0,554 & & & \\
Kons-K1 & 0,435 & 0,131 & $0,827^{* *}$ & $0,651^{*}$ & $0,880^{* *}$ & & \\
Kons-Y2 & 0,561 & 0,365 & $0,696^{*}$ & $0,675^{*}$ & 0,497 & $0,726^{*}$ & \\
Kons-K2 & $0,656^{*}$ & $-0,003$ & $0,698^{*}$ & 0,541 & 0,527 & $0,673^{*}$ & $0,785^{* *}$ \\
\hline
\end{tabular}

KM: Kuru madde verimi, Kons: Zn konsantrasyonu, Y: Yeșil aksam, K: Kök

${ }^{*} \mathrm{p}<0.05,{ }^{* *} \mathrm{p}<0.01$

Cizelge 4. Deneme süresince çözeltiden Zn' nun uygulanmadığı su kültürü ortamında, ekim öncesi tohumu farklı zaman aralıklarında ( 1 dk, 10 dk, 30dk ve 60 dk) 5 mM ZnSO$_{4}$ çözeltisinde bekletilerek Zn ile zenginleștirilmiș mısır bitkisinin I. ve II. hasatta saptanan mısır bitkisinin kök ve yeșil aksam kuru madde verimi ve kök ile yeșil aksam Zn konsantrasyon arasındaki korelasyon

Table 4. Correlation between root and shoot dry matter yield and root and shoot Zn concentration of corn plants having seeds soaked in $5 \mathrm{mM} \mathrm{ZnSO}_{4}$ solution at different durations (1 min, $10 \mathrm{~min}, 30 \mathrm{~min}$ and $60 \mathrm{~min}$ ) before sowing determined at I. and II. harvest under hydroponic media without Zn application

\begin{tabular}{|c|c|c|c|c|c|c|c|}
\hline \multicolumn{8}{|l|}{$\mathrm{Zn}(+)$} \\
\hline & $\mathrm{Km}-\mathrm{Y} 1$ & $\mathrm{Km}-\mathrm{K} 1$ & $\mathrm{Km}-\mathrm{Y} 2$ & $\mathrm{Km}-\mathrm{K} 2$ & Kons-Y1 & Kons-K1 & Kons-Y2 \\
\hline KM-K1 & 0,576 & & & & & & \\
\hline KM-YZ & $-0,288$ & $-0,295$ & & & & & \\
\hline KM-K2 & 0,059 & 0,514 & $-0,085$ & & & & \\
\hline Kons-Y1 & 0,145 & 0,213 & $-0,189$ & $-0,259$ & & & \\
\hline KonsK1 & 0,237 & 0,397 & 0,034 & $-0,009$ & $0,871^{* *}$ & & \\
\hline Kons-Y2 & $-0,095$ & $-0,028$ & 0,137 & $-0,220$ & $0,859^{* *}$ & $0,871^{* *}$ & \\
\hline Kons-K2 & 0,333 & 0,213 & $-0,128$ & $-0,061$ & $0,641^{\star}$ & $0,751^{*}$ & 0,622 \\
\hline
\end{tabular}

KM: Kuru madde verimi, Kons: Zn konsantrasyonu, Y: Yeșil aksam, K: Kök

${ }^{*} \mathrm{p}<0.05,{ }^{* *} \mathrm{p}<0.01$ 
artıșın II. hasatta daha düșük oranda seyretmesinin nedeni mevcut Zn'nun bitki büyümesini teșvik ederek kuru madde verimini arttırdığı ve bundan dolayı da dokularda bulunan Zn konsantrasyonunun seyrelmesiyle açıklanabilir (Torun vd., 2000; Marschner, 2012). Literatürde bu durum, Zn alımının artması kuru madde veriminin artıșına yol açmakta ve sonuçta alınan Zn artan kuru madde verimiyle birlikte seyrelmeye uğrarken, büyümesi daha az olan bitkilerde büyümenin engellenmesinden dolayı dokulardaki Zn'nun konsantre olmasıyla açıklanmaktadır (Marschner, 2012).

Yapılan çalıșmada Zn noksanlığı ile kök veya yeșil aksamdaki Zn konsantrasyonunun tam bir uyum vermediği bildirilmiștir. Örneğin, I.hasatta çözeltiden Zn'nun uygulanmadığı koșullarda tohumu $30 \mathrm{dk} \mathrm{ZnSO}{ }_{4}$ çözeltisinde bekletilen bitkinin kuru madde verimi kontrole göre \% 21 artmıș ve sözkonusu bitkideki Zn konsantrasyonunun 21,6 mg kg-1 olduğu görülmüștür. Aynı koșullarda II. hasatta aynı değerlerin \% 60 ve 16,3 $\mathrm{mg} \mathrm{kg}^{-1}$ olarak belirlenmiștir. Dolayısıyla Zn noksanlığını açıklamada önemli bir parametre olan kuru madde verimi ile Zn konsantrasyonu arasında anlamlı bir ilișki bulunamamıștır. Çinko konsantrasyonunun tek bașına Zn noksanlığını açıklamada yeterli olmadığı bașka araștıııcılar tarafından da bildirilmiștir (Torun vd., 2000; Cakmak vd., 2001, Marschner, 2012). Yapılan çalıșmalarda, bitki türleri veya aynı türün çeșitlerinin Zn noksanlığı altında semptomlarının șiddeti birbirlerinden büyük ölçüde farklı olmasına karșın, genellikle bitkinin yaprak veya yeșil aksamın kuru maddesinde hemen hemen eșit Zn konsantrasyonlarının bulunabileceği bildirilmiștir (Rengel ve Graham, 1995; Cakmak vd., 1996).

\section{SONUÇLAR}

Tohumu Zn'lu çözeltilerde bekleterek tohumu Zn ile zenginleștirme uygulamasıyla dane Zn konsantrasyonunu ve biyomas üretimini arttırmak hem bitki gelișimi hem de insan sağlığı açısından oldukça önemlidir. Dolayısıyla daneyi mikroelementlerce zenginleștirme uygulamasının yukarıda söylenen avantajlarının yanı sıra bu çalıșmada da birçok avantajının olduğu görülmüștür. Bunlar, her bir tohum mutlaka Zn ile muamele edilmiș olmakta ve bașlangıçta alınması gereken besin alımı garantilenmiș olmaktadır. Zn eksikliği görülen bitkilere Zn gübrelemesinin yanı sıra ekim öncesi tohumu Zn ile zenginleștirme uygulaması ile eksikliğin giderildiği görülmekte ve bitkinin intiyaç duyduğu Zn'yu kısmen karșılayabildiği belirlenmiștir.
Bundan sonra yapılacak çalıșmalarda, denemeye konu olan zaman ve konsantrasyonda ekimden önce tohumları $\mathrm{ZnSO}_{4}$ çözeltisinde bekletilen mısır bitkisinin gelișmesinin ileri așamalarında sözkonusu Zn'nun yeterli olamayacağı ve ilave $Z n^{\prime}$ ya intiyaç duyulabileceği saptanmıștır.

Cözeltiye Zn uygulaması yapılımıș ve yapılmamıș su kültürü koșullarında, ekim öncesi tohumu Zn ile zenginleștirilen bitkilerle yürütülen denemede sözkonusu uygulamanın etkin bir yöntem olduğu görülmüștür. Ancak, denemeye konu olan uygulamaların bitkinin dane verimi üzerine etkisini görmek için generatif dönemi de içine alan çalıșmaların yapılması gerekmektedir.

\section{KAYNAKLAR}

Afzal S (2013). Role of seed priming with zinc in improving the hybrid maize (Zea mays L.) yield. American-Eurasian Journal of Agricultural and Environmental Science, 13 (3): 301-306.

Ajouri A, Asgedom H, Becker M (2004) Seed priming enhances germination and seedling growth of barley under conditions of P and Zn deficiency. J Plant Nutr Soil Sci 167: 630636.

Cakmak I, Sari N, Marschner H, Ekiz H, Kalayci M, Yilmaz A, Braun H J (1996). Phytosiderophore release in bread and durum wheat genotypes differing in zinc efficiency. Plant and Soil 180: 183-189.

Cakmak I, Ekiz H, Yilmaz H, Torun B, Koleli N, Gultekin I, Alkan A, Eker S (1997). Differential response of rye, triticale, bread and durum wheats to zinc deficiency in calcareous soils. Plant and Soil 188: 1-10.

Cakmak I, Kalayci M, Ekiz H, Braun HJ, Kilinc Y, Yilmaz A (1999). Zinc deficiency as a practical problem in plant and human nutrition in Turkey: A NATO-Science for Stability Project. Field Crops Research 60: 175-188

Cakmak O, Ozturk L, Karanlik S, Ozkan H, Kaya Z, Cakmak I (2001). Tolerance of 65 durum wheat genotypes to zinc deficiency in a calcareous soil. Journal of Plant Nutrition 24 (11):1831-1847.

Cakmak I, Torun A, Millet E, Feldman M, Fahima T, Korol A, Nevo E, Braun HJ, Ozkan H (2004). Triticum dicoccoides: An important genetic resource for increasing zinc and iron concentration in modern cultivated wheat. Soil Science and Plant Nutrition 50 (7):1047-1054.

Cakmak I (2008). Enrichment of cereal grains with zinc: Agronomic or genetic biofortification? Plant and Soil 302 (12):1-17.

Cakmak I, Kalayci M, Kaya Y, Torun AA, Aydin N, Wang Y, Arisoy Z, Erdem H, Yazici A, Gokmen O, Ozturk L, Horst WJ (2010). Biofortification and Localization of Zinc in Wheat Grain. Journal of Agricultural and Food Chemistry 58 (16):9092-9102.

Ekiz H, Bagci SA, Kiral AS, Eker S, Gultekin I, Alkan A, Cakmak I (1998) Effects of zinc fertilization and irrigation on grain yield and zinc concentration of various cereals grown in zincdeficient calcareous soil. J Plant Nutr 21:2245-2256 
Foti R, Abureni K, Tigere A, Gotosa J, Gere J (2008). The efficacy of different seed priming osmotica on the establishment of maize (Zea mays L.) caryopses. J. Arid Environ. 72, $1127-$ 1130.

Gibson RS (2006). Zinc: the missing link in combating micronutrient malnutrition in developing countries. Proceedings of the Nutrition Society 65 (1):51-60.

Harris D, Rashid A, Miraj G, Arif M, Shah H (2007). Â Onfarm seed priming with zinc sulphate solution - A cost-effective way to increase the maize yields of resource-poor farmers. Field Crops Res. 10, 119-127.

Marschner H. (2012). Marschner's Mineral Nutrition of Higher Plants, 3rd Edn London: Academic Press.

Ortiz-Monasterio Jl, Palacios-Rojas N, Meng E, Pixley K, Trethowan R, Pena RJ (2007). Enhancing the mineral and vitamin content of wheat and maize through plant breeding.Journal of Cereal Science 46: 293-307.

Özturk L, Yazici MA, Yucel C, Torun A, Cekic C, Bagci A, Ozkan H, Braun HJ, Sayers Z, Cakmak I (2006). Concentration and localization of zinc during seed development and germination in wheat. Physiologia Plantarum 128 (1):144-152
Prom-u-thai C, Rerkasem B, Yazıcı M.A, Cakmak, I (2012). Zinc priming promotes seed germination and seedling vigor of rice", Journal of Plant Nutrition and Soil Science, Vol. 175, No.3, 482-488.

Rengel Z, Graham RD (1995) Importance of seed Zn content for wheat grown on Zn-defi cient soil, I: Vegetative growth. Plant and Soil 173: 259-266

Torun B, Bozbay G, Gultekin I, Braun H.J, Ekiz H, Cakmak I. (2000). Differences in shoot growth and zinc concentration of 164 bread wheat genotypes in a zinc-deficient calcareous soil

Wissuwa M, Ismail AM, Yanagihara S (2006): Effects of zinc deficiency on rice growth and genetic factors contributing to tolerance. Plant Physiol., 142, 731-741

Yılmaz A, Ekiz H, Torun B, Gultekin I, Karanlik S, Bagci SA, Cakmak I (1997) Effect of different zinc application methods on grain yield and zinc concentration in wheat cultivars grown on zinc-deficient calcareous soils. J Plant Nutr 20:461-471

Zhang F, Gao X, Zou C (2007). Soil and Crop Management for Improving Zinc Nutrition of Crops.http://mww.zinccrops.or g/ZnCrops2007/PDF/2007_zinccrops2007_zhang_keynote.pdf 